\title{
Use of Damar Kurung Media in Science Learning in Primary School to improve Learning outcomes
}

\author{
Mintohari $^{\mathrm{a}}$, Budiono Sadiman ${ }^{\mathrm{b}}$, Pamela Ayu Larasatic \\ ${ }^{\mathrm{abc}}$ Departemen Elementary Teacher Education, Surabaya State University, Surabaya, Indonesia \\ Corresponding e-mail: amintohari@unesa.ac.id
}

\begin{abstract}
Damar Kurung is one of the unique forms of cultural art from Gresik, East Java, Indonesia, in the form of rectangular lanterns, its material is made of paper, its frame is made of bamboo, and on each side is painted with a certain story. This cultural art has a very high value and its existence must be preserved. One performed strategy is to introduce this art to children early. How to introduce the art of this culture can be through academic and non academic activities. Through the academic activities of means the art of Damar Kurung injected through the learning activities in the classroom. In this research implement Damar Kurung in science learning in elementary school. The implementation form is the use of Damar Kurung as a medium of science learning in elementary school. The purpose of this study to determine the effect of using Damar Kurung media on the results of science learning elementary school students. In this study using quasi experimental research with design Nonequivalent Control Group Design. From the data collection activity, it was found that the difference of pretest and postes average of the experimental class was higher when compared with the difference of pretest postes control class. After the t-test count shows a significant difference between the average difference between pretest and postes of the experimental class and the difference between the pretest postes of the control class. From the analysis it can be concluded that the use of media Damar Kurung affect the results of science learning elementary school students.
\end{abstract}

Keywords: $\quad$ Damar Kurung; science learning

\section{INTRODUCTION}

Damar Kurung is one of the distinctive forms of cultural art from Gresik, East Java, Indonesia, in the form of rectangular lanterns, made of paper, made of bamboo, and on each side is painted with a certain story. This cultural art has a very high value and its existence must be preserved. One strategy that is done is to introduce this art to the child early. How to introduce the art of this culture can be through academic and non academic activities. Currently, the preservation of damar kurung is mostly done through painting gallery in Gresik area. In this way, can not disseminate children, so the socialization of damar kurung art can not run well. Through the academic activities which means entering the art of damar kurung through the learning activities in the classroom. How to incorporate the art of brackets in learning activities can be through culture art lesson or through other subjects as a learning medium. In this research try to implement Damar Kurung in science learning in elementary school. The implementation form is the use of Damar Kurung as a medium of science learning in elementary school. Previous research has been done by previous researchers include Carney, Russell N., and Joel R. Levin who examined the illustration of the picture. From this research the results show that the illustration in the text can improve the students' learning ability ${ }^{2}$. In addition, Yen, Jung-Chuan in his research also found that groups of students using learning image-based with mapping concept showed a higher level of understanding and creation than Text-based group ${ }^{7}$. In addition, Lewalter's research, Doris, shows that there is a significant difference in learning outcomes between computer-based learning illustrated with images and using only text ${ }^{6}$. From the three studies show that the use of image media in learning activities has an influence on the achievement of student learning outcomes.

That distinguishes this research with the previous study is the image used as a learning medium in this study painted on Damar Kurung which is a typical art of Gresik, East Java, Indonesia. This has not been done by previous researchers. By using the media images painted in Damar Kurung, in addition to make students more interested, can also introduce and preserve the culture of the region from to the students in the early age. Thus there are two main things that will be obtained by students in the learning activities that is increasing the involvement of students in learning that will lead to master of material substance studied and students will be more familiar, appreciate, and then preserve the local culture.

Something that is expected by the use of Damar Kurung as a medium of learning natural science is the students become more interested in learning activities, student involve in learning activities more intense and at last, students will master the various science concepts learned in the classroom deeper. This can lead to students' learning outcomes increased. In addition, through the use of media Damar Kurung in science learning in elementary 
school, students will be more familiar with the cultural arts typical of their of residence and eventually participate preserve the art and culture. Damar Kurung according to Ismoerdijahwati is a lamp that is closed by using certain materials and on the cover there is decoration in the form of painting with motif ${ }^{4)}$ Painting on cover Damar Kurung in the form of story with certain theme ${ }^{5)}$. One of the painting characteristics contained in the cover Damar Kurung A story that has a certain flow, then not all the material in the natural science can be taught by using Danar Kurung media. The material used in Damar Kurung media has a certain flow. For that in this studies try to implement Damar Kurung as medium of science learning on water cycle material. Damar Kurung used as a learning medium is a modified Damar Kurung. The modification done by the researcher is to change the story image located on Damar Kurung cover with water cycle picture.

\section{METHODS}

This research uses quasi experimental research with Design Nonequivalent Control Group Design. The study was conducted in the even semester of the academic year 2016/2017. The population of this study is the entire class $\mathrm{V}$ in SD Negeri 3 Sidokumpul Gresik in the even semester academic year 2016/2017. Samples taken as many as 2 classes with the number of 60 students of VB class as many as 30 students and VC class as many as 30 students. The sampling of this research conducted the selection of purposive sampling. While the instrument of this study using the test sheet. The test sheet is used to collect student learning result data. The test sheet consists of pre-test and post-test sheets. The data of the research were analyzed by $t$ test statistical test.

\section{RESULT AND DISCUSSION}

The students' learning result from control class and experiment class can be seen from the diagram below:

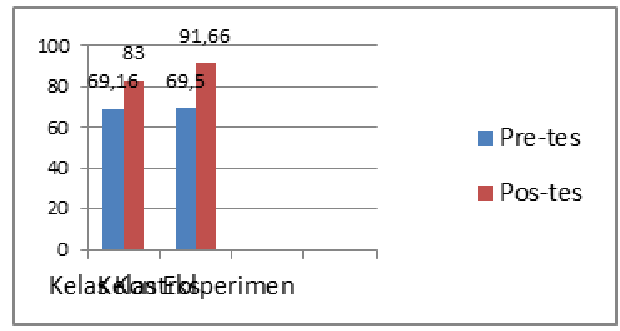

Figure 4.1 Study Result

From the diagram 4.1 students' cognitive learning result can be known through pre-test and post-test. In the control class obtained an average pre-test value of 69.16 and the average post-test value of 83 . While in the experimental class obtained an average value of pre-test 69.5 and post-test value 92.66. This shows that there is a difference in the improvement of learning result in the control class and the experimental class using the Damar Kurung media. Furthermore, to know the significance of the difference in the increase of learning outcomes between the control class and the experimental class is t-test. Based on t-test results can be seen that the media damar kurung provide a significant influence on student learning result. It can be seen from the difference of gain result which is significant between control class average gain score 0,47 which is included in medium category and experimental class average gain score 0,71 which is included in high category. From the results of t test calculation, to see whether there is influence that is by looking -t_count $<-$ t_tabel. In the calculation of t-test with SPSS 22 obtained $-2,611$ results $<-2.002$ it can be concluded that $\mathrm{Ha}$ accepted or there is a significant difference between posttest result of control class and experiment class. It means there is a significant influence between giving treatment in the form of media use damar kurung on student learning result.

The increase of learning outcomes by using medium Damar Kurung is caused by the increased involvement of students in learning activities. Student involvement in this learning activity is a manifestation of student interest in the learning media used. This is evident from the activities shown by the students in the learning activities. Students seem enthusiastic to observe the pictures contained in Damar Kurung media cover. Even among them many are curious and ask about various things about images and art Damar Kurung. Thus learning by using medium brackets can create an active, effective and fun classroom atmosphere. Students are more enthusiastic in following the learning activities and this affects the increasing mastery of subject matter by students. Astriani reveals that conceptual understanding is the ability of students to grasp the meaning of a concept and re-expose the concept in detail in different situations and forms and be able to solve problems related to the concept. To gain an understanding of concepts, students must be able to play an active role in teaching and learning activities so that they gain a learning experience so that students can remember concepts that have been studied for long periods of time ${ }^{\mathbf{1}}$. This is also consistent with the results of research from Ford, J. Kevin, Et al that is the involvement of students in the activities of learning has a relationship with the acquisition of student knowledge in learning activities ${ }^{4}$. In addition, through learning by using media Damar Kurung will also train children to be independent in finding the various concepts studied. This can be seen from the involvement of the students start from observing the picture contained in Damar Kurung, recording the observation, doing the interpretation of observation data and discussing in 
the group to formulate the conclusion. Student activity will indirectly train students to learn independently. Through independent learning will be able to improve the mastery of teaching materials by students. This is consistent with the results of research conducted by Dignath, Charlotte, Gerhard Buettner, and Hans-Peter Langfeldt, who stated that self-learning has an effect on the achievement of students' academic learning outcomes ${ }^{3}$.

\section{CONCLUSION}

From this research, it can be concluded that the use of media Damar Kurung significantly influence the improvement of science learning outcomes of grade V SD students.

\section{REFERENCES}

[1] Astriani, Desy. (2012). Peningkatan Pemahaman Konsep Daur Air Menggunakan Media Audio Visual Digital Versatile Disc. http://jurnal.fkip.uns.ac.id/index.php/pgsdsolo/ar ticle/view/2750. (Diakses Pada Tanggal 29 September 2016 Pukul 17:17)

[2] Carney, Russell N., and Joel R. Levin. (2002). Pictorial illustrations still improve students learning from text. Educational psychology review, 14,1, pp. 5-26

[3] Dignath, Charlotte, Gerhard Buettner, and HansPeter Langfeldt. (2008). How can primary school students learn self-regulated learning strategies most effectively A meta-analysis on selfregulation training programmes. Educational Research Review, 3, 2, pp. 101-129.

[4] Ford, J. Kevin, et al. (1998). Relationships of goal orientation, metacognitive activity, and practice strategies with learning outcomes and transfer. Journal of applied psychology, 83, 2, pp. 218.

[5] Ismoerdjahwati, Ika. (2014). Budaya Nusantara Melalui Damar Kurung, 1,.1, pp. 84-91. Http://Www.Digilib.Itb.Ac.Id/Files/Disk1/35/Jb ptitbpp-Gdl-S2-2001- Ismoerdija-1726-T.SeniH-A.Pdf. (Diakses Pada Tanggal 29 September 2016 Pukul 17:11)

[6] Lewalter, Doris. (2003). Cognitive strategies for learning from static and dynamic visuals. Learning and Instruction, 13, 2, pp. 177189.

[7] Yen, Jung-Chuan, Chun-Yi Lee, and I. Chen. (2012). The effects of image-based concept mapping on the learning outcomes and cognitive processes of mobile learners. British Journal of Educational Technology,43, 2, pp. 307-320. 